\title{
22
}

\section{Industrial location and regional development}

\section{Jane Golley}

Rising regional inequality has become an undeniable aspect of China's economic reform and development during the last 25 years. Throughout the 1990 s and into the 2000 s inter-provincial disparities in per capita income have continually increased. It is generally accepted that diverging rates of development in the coastal (or eastern) and interior (or central and western) provinces are a major source of these income disparities (Yang 1997; Démurger 2001; Yao and Zhang 2001; Bao et al. 2002). This divergence, in turn, stems largely from the regional pattern of China's industrial development during the same period (Lyons 1991; Yao 1997; Mody and Wang 1997; Fujita and Hu 2001; Golley 2002). It is this pattern which is the primary focus of this chapter.

Regional development has always been an integral part of the Chinese Communist Party's policy agenda. Soon after their rise to power in 1949, developing China as a major industrial and military power became the number one priority. But distributional and equity goals were also important. In particular, the government sought a more even geographical distribution of industry, claiming that foreign domination had resulted in an 'irrational' pattern of industrial development, in which output capacity was concentrated in coastal China. Mao Zedong was determined to achieve a more balanced geographical distribution of industry for strategic military purposes, and also because, in the long run, growth leading to increasing regional inequalities ran counter to the goal of creating a politically unified and economically integrated nation 
state (Lardy 1978). The relocation of industrial capacity was achieved through the nationalisation of industry and an increasing share of state investment allocated to 'backward', that is, interior, provinces, in what became know as the 'Interior Development Strategy'. While it is widely acknowledged that the strategy was fraught with economic inefficiencies, it is an indisputable fact that the geographical structure of industry was levelled out to some extent: in 1953 the interior accounted for 31 per cent of national gross value of industrial output (GVIO); by 1978 this share had increased to 46 per cent.

Regional development has also been a major component of the economic reforms since they commenced in the late 1970s. The 1980s witnessed a significant shift in regional policy towards the coastal region. The primary focus on efficiency and rapid growth justified the promotion of the more developed coastal region, with Deng Xiaoping (1984:45) arguing that 'since conditions for the country as a whole are not ripe, we can have some areas become rich first. Egalitarianism will not work.' This policy stance was made clear from the onset, with the introduction of the Open Door Policy and the establishment of special economic zones (SEZs) in the coastal provinces of Guangdong and Fujian. The 'Coastal Development Strategy', adopted by the CPC Central Committee and the State Council in March 1988, formally endorsed the shift in policy, calling for development to extend 'progressively from the special economic zones to coastal cities, then to coastal economic regions and finally to interior areas' (Zhao 1987:27). Indeed, it was always the intention that the focus on the coastal region would ultimately shift towards the rest of the country. According to Deng (1986:163), 'The purpose of allowing some regions and some people to become prosperous before others is to enable all of them to prosper eventually. We have to make sure there is no polarisation of society-that's what socialism means.'

In contrast with the Seventh Five-Year Plan (1986-90), which clearly favoured coastal provinces, the Eighth Five-Year Plan (1991-95) advocated an absence of regional favouritism and a more level playing field. This was a political response to increasing discontent and widespread criticisms from interior provinces regarding the divergent levels of development in the first decade of reforms. However, the shift was undermined by Deng Xiaoping's 'southern tour' in 1992, during which he strongly supported more rapid growth in the southeastern provinces, and also by declining revenues, which limited the central government's ability to back its policies with 
fiscal measures. Policy proved inadequate to reverse the trend of the coastal region's share of industrial output, which rose steadily from 55 per cent of the national total in 1978 to 65 per cent in 1995.

The Ninth Five-Year Plan (1996-2000) indicated a further strengthening of the central government's commitment to addressing regional disparities. Numerous fiscal, credit and investment-based measures, combined with policies to encourage foreign trade and investment, and measures to enhance co-operation between coastal and interior provinces were implemented during this period. In 2000 both Prime Minister Zhu Rongji and President Jiang Zemin said that the large-scale development of central and western China was a major policy decision for the new century (Zhu 2000; Zeng Peiyan 2000). During the Tenth Five-YearPlan (2001-05), and now under the new leadership of Hu Jintao, Jiang's 'Western Development Strategy' or 'Go West Campaign' is continuing to receive emphasis, as witnessed by a surge of statements during the Tenth National Party Congress in March 2003 (for example, China Daily, 3 March, 5 March, 6 March, 13 March 2003). Despite this policy strengthening, however, the coast has continued to increase its share of the national gross value of industrial output, reaching 72 per cent in 2001.

The key point to take from all of this is simple: regional development matters to the Chinese government. In particular, the location of industrial development-and its implications for regional patterns of income inequality-matters. ${ }^{2}$ Moreover, the government's approach to regional development is far from laissez faire: its current objective is to alleviate the inequalities that it hitherto helped to create. What combination of policies, if any, would enable the government to succeed in this endeavour, is an extremely complex question that cannot be resolved here. ${ }^{3}$ Instead, the objective is to highlight some of the key issues that need to be taken into account.

\section{'LOCATION' MATTERS}

\section{Background}

The idea that the agglomeration of production in a particular location yields advantages, and that these advantages in turn explain such agglomeration is vital for understanding the spatial unevenness of industry and development. Consider a multi-region economy in which 'transport costs' (interpreted broadly to include not only physical transport costs but also the informational, sales, and support 
complications involved in doing business at a distance) are initially so high that industry is distributed across regions in accordance with population in order to serve isolated local markets (that is, there is no inter-regional trade). Note also that this is not an entirely unreasonable representation of China prior to 1978, when transport development lagged well behind other aspects of national development and provinces were highly self-sufficient.

Now consider an economic reform and development process which leads to a gradual reduction in 'transport costs', thereby eliminating the need to locate production perfectly in line with demand. In the presence of economies of scale and interindustry-or cost and demand-linkages, this draws firms to the larger markets in order to benefit from access to their larger (and hence cheaper) supply of intermediate inputs. In some industries, firms will be drawn to the larger market in order to benefit from externalities associated with knowledge or technological spillovers. As long as there is some degree of inter-regional labour mobility, workers will also be drawn to larger markets in order to access higher wages (as in the case of China's 'floating' population). The result will be industrial agglomeration, which will be accompanied by relatively rapid growth of per capita GDP and hence rising regional inequality. According to Myrdal (1957), exactly where that agglomeration occurs will come down to an 'accident of history'. Regardless of the precise nature of that 'accident', the process of agglomeration in one location, and not another, results in a cumulative process where that location industrialises ahead of the rest. In other words, location matters.

However this process is not boundless. As long as there is some degree of interregional labour immobility (which in China there is), rising wages in the agglomerating region will lead to rising costs, which will offset the reduced costs stemming from more intermediate inputs and other externality-driven benefits. As 'transport costs' continue to fall, wage and other cost differentials may reach a point where it is optimal for firms to relocate to less-developed regions. That is, the benefits of industrial agglomeration in a 'Core' region will eventually 'trickle down' or 'spread' to the 'Periphery'. ${ }^{4}$ In the (theoretical) long run, industry is evenly spaced across the economic landscape and per capita incomes are equalised. Adopting Krugman's (1995) interpretation of 'transport costs' $(\tau)$ as a proxy for economic development, this generates an inverted U-shaped pattern between economic development and industrial agglomeration over time. ${ }^{5}$ There is significant evidence to suggest that China lies on the upside of that $U$, with rising industrial agglomeration in coastal 
provinces and rising coast-interior income inequality. ${ }^{6}$ However it is not quite that clear cut. What is needed is an empirical means of identifying exactly where industrial agglomeration is occurring. This will be in those provinces which have 'locational' advantages for industrial development. This is where shift-share analysis comes in.

\section{Shift-share analysis $^{7}$}

Let $\Delta Y_{i j}$ denote the change in output for the th sector in region $j$ from the base period to the end period. By definition, it is the product of total output of the th sector in region $j$ in the base period, $Y_{i j 0,}$ multiplied by the growth rate of output of the th sector in region jover the whole period, $R_{i j}$;

$$
\Delta Y_{\mathrm{ij}}=Y_{i j} R_{\mathrm{ij}}
$$

Let $R_{k}$ and $R_{i k}$ denote growth rates of output for the country and for the ith sector of the country respectively. Equation 22.1 can then be decomposed into three components:

$$
\Delta Y_{i j}=Y_{j 0} R_{k}+Y_{j 0}\left(R_{i k}-R_{k}\right)+Y_{j 0}\left(R_{i j}-R_{i k}\right)
$$

Figure 22.1 Pattern of agglomeration

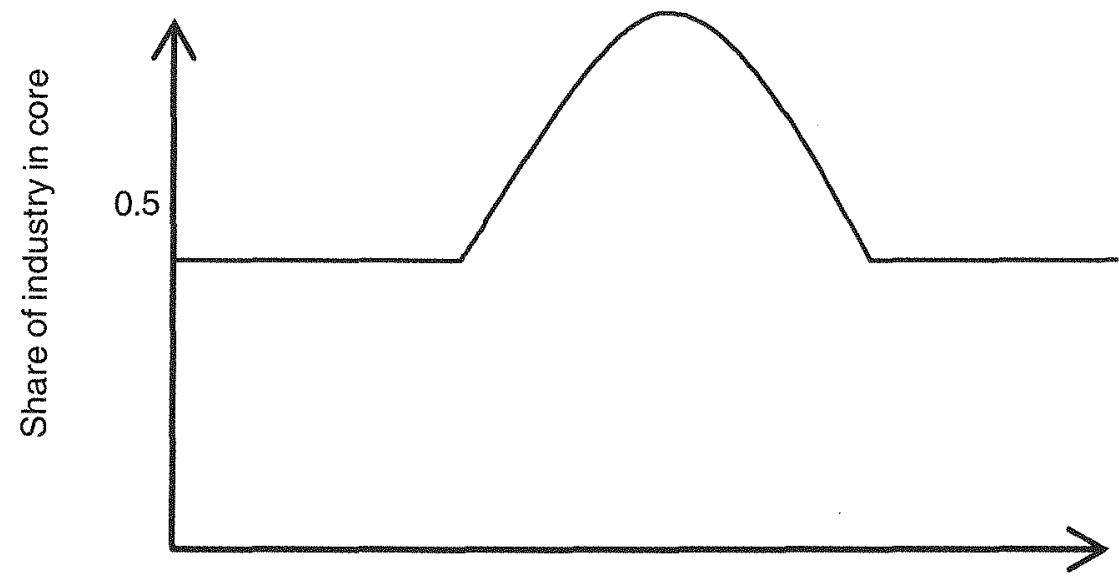


The first term on the right-hand side of Equation 22.2 is called the national component of growth. It shows, ceteris paribus, the growth that would have resulted had sector $i$ in location $j$ exactly matched the national trend $\left(R_{k}\right)$. The second term is the structural component. It calculates the change in the th sector that can be attributed to the region's industry mix. If the region has a 'favourable' mix, comprising more industries that are experiencing rapid growth (higher $R_{i k}$ ), it will, ceteris paribus, experience faster output growth than the rest of the country.

However, having a favourable industrial structure in the base period is neither a necessary nor a sufficient condition for faster growth. The third term on the right hand side is often called the differential (or residual) component, because it is the part of regional growth not explained by the national and structural components. It is a catch-all for measuring the extent to which sector $i$ in region $j$ grew faster or slower than it would have had the local industry experienced the national growth rate (in the former, $R_{i j}>R_{i k}$ so that the value is positive). For this reason, it makes perfect sense to call it the locational component, which is the terminology adopted here.

Finally, Equation 22.2 can be rearranged as follows

$$
\Delta Y_{i j}-Y_{i j 0} R_{k}=Y_{i j 0}\left(R_{i k}-R_{k}\right)+Y_{i j 0}\left(R_{i l}-R_{i k}\right)
$$

The left-hand side is the 'net relative change'(NRC), which is the difference between the actual change and the national component. The NRC shows whether the th sector in region j experienced faster or slower growth of industrial output than the national average, with a positive value reflecting the former. The NRC can therefore be regarded as an index of relative performance, which the right-hand side seeks to explain.

As Equation 22.3 shows, each NRC can be decomposed into its structural and locational components (SC and LC respectively). In total, there are six different combinations of signs on the NRC, SC and LC (Table 22.1).

In Types 1,2 and 3 the NRC is positive, which translates to a growth rate above the national average. Identifying those provinces that record positive NRCs will provide one way of determining where industrial agglomeration is occurring in each sector. In Types 1, 3 and 6, locational factors make a positive contribution to the $\mathrm{NRC}$, that is, to the growth of manufacturing output, which means we can identify which provinces have location working in their favour. A closer look at the actual figures will also provide a measure of the importance of location (as opposed to sectoral structure) in determining provincial industrial performance. This will enable us to establish a clear case that location does indeed matter. 
Table 22.1 NRC, SC and LC combinations

\begin{tabular}{lccc}
\hline Type & NRC & SC & LC \\
1 & + & + & + \\
2 & + & + & - \\
3 & + & - & + \\
4 & - & - & - \\
5 & - & + & - \\
6 & - & - & + \\
\hline
\end{tabular}

\section{EMPIRICAL RESULTS}

Since 1978 China has recorded an average annual rate of real GDP growth of around 10 per cent, a remarkable growth rate by any standards. However, this growth has not been evenly distributed across the country. Provincial rates of real GDP growth between 1978 and 2001 ranged between 13.5 per cent in Fujian (in the East) to 7 per cent in Gansu (in the West) (Table 22.2). Note that the top five provinces in terms of GDP growth are the five Southeastern provinces, Fujian, Guangdong, Zhejiang, Shandong and Jiangsu. It is also interesting to see that Xinjiang (aWestern province) and Henan (a Central province) are the next two provinces in the ranking. Shanghai, on the other hand, ranks second to last, while Liaoning (another coastal province) is also a relatively poor performer in terms of GDP growth.

The table also ranks provinces in terms of changing shares of the gross value of industrial output over the same period. While there is not a one-for-one matching with the GDP ranking, there is a strong correlation (of 0.93 ). The top seven provinces in terms of GDP growth are also the top seven in terms of increases in GVIO shares, while Shanghai and Liaoning both record declining GVIO shares. This correlation follows through to changes in per capita GDP, as shown in the final four columns. Zhejiang's per capita GDP, for example, was 0.87 times the national average in 1978, increasing to 1.94 times the national average in 2001. This implies that Zhejiang recorded the fastest growth of per capita GDP during that period. Again, the same provinces rank in the top seven, while Shanghai remains at the bottom of the ranking. The correlation between per capita GDP growth and growth of GVIO is 0.90 , while the correlation between per capita GDP growth and GDP growth is 0.91 .

It is not surprising that GVIO growth is strongly correlated with growth rates of GDP and per capita GDP. This implies that understanding provincial disparities in 
Table 22.2 Rankings of GDP growth, GVIO shares, and changes in per capita GDP

\begin{tabular}{|c|c|c|c|c|c|c|c|}
\hline Province & $\begin{array}{l}\text { Real GDP } \\
\text { growth } \\
1978-2001\end{array}$ & Province & $\begin{array}{l}\text { Change in } \\
\text { share of } \\
\text { GVIO }\end{array}$ & Ratio provincial & $\begin{array}{r}\text { Ratio } \\
1978\end{array}$ & $\begin{array}{l}\text { Ratio } \\
2001\end{array}$ & $\begin{array}{l}\text { apita GDP } \\
\text { Change in } \\
\text { ratio } \\
1978-2001\end{array}$ \\
\hline & & & & & & & \\
\hline Fujian & 13.5 & Guangdong & 10.0 & Zhejiang & 0.87 & 1.94 & 1.07 \\
\hline Guangdong & 12.9 & Zhejiang & 5.3 & Fujian & 0.72 & 1.64 & 0.92 \\
\hline Zhejiang & 12.7 & Jiangsu & 4.3 & Guangdong & 0.97 & 1.82 & 0.85 \\
\hline Shandong & 11.4 & Shandong & 3.1 & Jiangsu & 1.13 & 1.71 & 0.58 \\
\hline Jiangsu & 10.9 & Fujian & 1.7 & Shandong & 0.83 & 1.39 & 0.55 \\
\hline Xinjiang & 10.9 & Henan & 0.3 & Xinjiang & 0.83 & 1.05 & 0.22 \\
\hline Henan & 10.5 & Xinjiang & 0.2 & Henan & 0.61 & 0.79 & 0.17 \\
\hline Hubei & 9.9 & Inner Mongolia & 0.1 & Hubei & 0.88 & 1.04 & 0.16 \\
\hline Hebei & 9.8 & Ningxia & -0.02 & Hebei & 0.96 & 1.11 & 0.15 \\
\hline Yunnan & 9.8 & Yunnan & -0.1 & Yunnan & 0.60 & 0.65 & 0.05 \\
\hline Guangxi & 9.7 & Qinghai & -0.2 & Anhui & 0.64 & 0.69 & 0.05 \\
\hline Anhui & 9.6 & Guizhou & -0.3 & Hunan & 0.75 & 0.80 & 0.05 \\
\hline Hunan & 9.3 & Hubei & -0.4 & Sichuan & 0.67 & 0.71 & 0.04 \\
\hline Inner Mongolia & 9.2 & Anhui & -0.6 & Guangxi & 0.59 & 0.62 & 0.03 \\
\hline Beijing & 9.1 & Guangxi & -0.6 & Inner Mongolia & 0.84 & 0.86 & 0.02 \\
\hline Sichuan & 8.9 & Jiangxi & -0.6 & Jilin & 1.01 & 1.01 & 0.01 \\
\hline Jiangxi & 8.9 & Tianjin & -0.7 & Beijing & 3.40 & 3.38 & -0.02 \\
\hline Jilin & 8.9 & Hebei & -0.8 & Jiangxi & 0.73 & 0.69 & -0.04 \\
\hline Guizhou & 8.6 & Jilin & -0.8 & Guizhou & 0.46 & 0.38 & -0.08 \\
\hline Ningxia & 8.5 & Shaanxi & -0.9 & Shaanxi & 0.77 & 0.67 & -0.10 \\
\hline Shaanxi & 8.5 & Gansu & -0.9 & Liaoning & 1.79 & 1.60 & -0.20 \\
\hline Tianjin & 8.4 & Shanxi & -0.9 & Shanxi & 0.96 & 0.72 & -0.24 \\
\hline Liaoning & 8.3 & Hunan & -1.4 & Heilongjiang & 1.49 & 1.24 & -0.25 \\
\hline Heilongjiang & 7.9 & Beijing & -1.6 & Ningxia & 0.98 & 0.71 & -0.27 \\
\hline Shanxi & 7.9 & Sichuan & -1.8 & Gansu & 0.92 & 0.55 & -0.37 \\
\hline Qinghai & 7.7 & Heilongjiang & -2.4 & Qinghai & 1.13 & 0.76 & -0.37 \\
\hline Shanghai & 7.4 & Liaoning & -4.7 & Tianjin & 3.06 & 2.67 & -0.39 \\
\hline Gansu & 7.0 & Shanghai & -5.6 & Shanghai & 6.59 & 4.96 & -1.64 \\
\hline
\end{tabular}

Source: Figures drawn from State Statistical Bureau (SSB) $(1997,2002)$ and calculated by author. 
industrial performance is a critical component of understanding regional income disparities more generally. It is perhaps more interesting to observe that the standard East-Centre-West and coast-interior regional classifications obscure the fact that each region has some provinces performing well and others performing badly. This is a particularly important point in light of the central government's tendency to focus on these classifications when formulating regional policies.

The empirical analysis that follows draws on a dataset of GVIO for 30 provinces and 28 manufacturing sectors drawn from China Industrial Economic Statistical Yearbooks (State Statistical Bureau 1990, 1995, 2001). Table 22.3 presents gini coefficients for each sector in 1989, 1994 and 2000. Gini coefficients measure the extent of geographical concentration (or agglomeration) in specific manufacturing sectors relative to the level of manufacturing concentration overall. The closer the provincial spread of a particular sector is to the provincial spread of manufacturing overall, the closer the gini is to zero. The more concentrated a certain sector is, the closer the gini is to one. As the table shows, in all but two sectors (wood products and petroleum processing and coking), the gini coefficient rose between 1989 and 2000, suggesting that Chinese industry is indeed becoming more agglomerated. It remains to be seen in which provinces this agglomeration is taking place, and why. Focusing on the period 1994-2000, this is the main task of this section. ${ }^{8}$

Several preliminary points are worth highlighting. First, the coastal region's 74 per cent share of national manufacturing output is far above its population share of 42 per cent. This dominance exists across the board, with the coastal region producing 92 per cent of all clothing, 89 per cent of leather and furs, 97 per cent of cultural, educational and sports goods (CESG) and 90 per cent of electronic and telecommunications equipment (ETE). The region produces more than 60 per cent of output in all but two sectors and at least 80 per cent of output in close to half the sectors.

Second is the dominance of certain provinces. In 2000 Guangdong, with 7 per cent of China's population, produced more than a quarter of its clothes, leather and furs, CESG, furniture, plastics, electronic equipment and machinery (EEM), ETE, and instruments and metres. Jiangsu produced almost a quarter of the nation's chemical fibres, machines and textiles, while Shandong produced more than 20 per cent of its food processing manufactures, rubber products and special purpose equipment. Zhejiang produced 17 per cent of China's textiles and clothing, and neighbouring Shanghai, with less than 2 per cent of the nation's population, produced 
19 per cent of chemical fibres, 14 per cent of transport equipment and 12 per cent of smelting and pressing ferrous metals (SPFM). In combination with Fujian, these six contiguous provinces produced 57 per cent of national manufacturing output in 2000 . This seems to suggest that industry is concentrated at both the regional and provincial levels along China's southeastern coast.

Not only does the coastal region dominate manufacturing production, but its share has risen over time. Between 1994 and 2000, the region increased its share of China's manufacturing output by 5.0 percentage points. This followed an increase of 6.5 percentage points between 1989 and 1994. At the provincial level, Guangdong experienced an increase of 4.4 percentage points during the last six years, on top of 4.1 percentage points in the previous period. Zhejiang, Shandong and Fujian all experienced further increases in their shares, while Liaoning and Guangxi suffered further declines. Shanghai, Beijing, Tianjin and Hebei, in contrast with the early 1990s, also saw their shares increase between 1994 and 2000. The only non-coastal provinces that increased their output shares were Henan, Xinjiang and Tibet. The continuing rise in the coastal region's share of manufacturing over time translates to industrial agglomeration there. ${ }^{9}$ But note that this agglomeration is not benefiting all coastal provinces.

Table 22.4 presents the net relative changes, structural components and locational components for each sector in each province between 1994 and 2000 , classifying each of the 1,108 observations as Types 1-6 following the methodology introduced above. Note first some simple information contained in the table. The final column records the NRCs for total provincial output. In a sense this captures the overall 'locational' value of each province (since the NRC at the provincial level is based solely on the locational components). These will be positive for those provinces in which manufacturing overall grew above the national average, which translates to those provinces which increased their output shares. This is only the case for the provinces mentioned in the previous paragraph, revealing that manufacturing growth is skewed in favour of a small number of provinces. The bottom row of the table records the NRC at the national level for each sector, which is equivalent to the SC (since the LC is zero at the national level). These will be positive for all sectors which grew above the national average.

As Table 22.4 shows, however, there is no guarantee that a positive SC will result in a positive $\mathrm{NRC}$, since locational factors may still manage to drag the growth rate of a given sector in a given province below the national average (Type 5). This is the 
case, for example, in Guangxi's food manufacturing sector, which has a positive SC but a negative NRC. This is because the LC for food manufacturing is negative and large enough to override the positive SC. That is, despite the fact that the sector grew above the national average, when located in Guangxi it dropped to below average. In the furniture sector this is the case for all western provinces other than Xinjiang, while in the transport equipment sector it is the case for all western provinces other than Sichuan. Surely an entrepreneur producing in these sectors would prefer to locate elsewhere.

Table 22.3 Gini coefficients

\begin{tabular}{|c|c|c|c|}
\hline & 2000 & 1994 & 1989 \\
\hline Food processing & 0.316 & 0.236 & .. \\
\hline Food manufacturing & 0.227 & 0.208 & .. \\
\hline Beverages & 0.245 & 0.236 & 0.234 \\
\hline Tobacco & 0.616 & 0.612 & 0.492 \\
\hline Textiles & 0.348 & 0.321 & 0.253 \\
\hline Clothing and other chemical fibres & 0.403 & 0.366 & 0.232 \\
\hline Leather and furs & 0.446 & 0.358 & 0.216 \\
\hline Wood products & 0.234 & 0.308 & 0.403 \\
\hline Furniture & 0.276 & 0.262 & 0.216 \\
\hline Paper making & 0.236 & 0.223 & 0.188 \\
\hline Printing and record medium & 0.272 & 0.182 & 0.187 \\
\hline Cultural, educational and sports articles & 0.501 & 0.462 & 0.499 \\
\hline Petroleum processing and coking & 0.367 & 0.380 & 0.444 \\
\hline Chemical materials & 0.186 & 0.140 & 0.156 \\
\hline Medical and pharmaceutical products & 0.239 & 0.165 & 0.145 \\
\hline Chemical fibres & 0.402 & 0.375 & 0.372 \\
\hline Rubber & 0.301 & 0.233 & 0.162 \\
\hline Plastics & 0.315 & 0.292 & 0.243 \\
\hline Non-metal mineral products & 0.196 & 0.180 & 0.147 \\
\hline Smelting and pressing of ferrous metals & 0.409 & 0.370 & 0.338 \\
\hline Smelting and pressing of non-ferrous metals & 0.396 & 0.367 & .. \\
\hline Metal products & 0.262 & 0.156 & 0.138 \\
\hline Universal machines & 0.299 & 0.195 & 0.118 \\
\hline Special purpose equipment & 0.309 & 0.201 & .. \\
\hline Transportation equipment & 0.350 & 0.314 & 0.305 \\
\hline Electric equipment and machinery & 0.270 & 0.239 & 0.206 \\
\hline Electronic and telecommunications equipment & 0.479 & 0.464 & 0.340 \\
\hline Instruments and metres & 0.414 & 0.312 & 0.282 \\
\hline
\end{tabular}

Source: SSB(1990, 1995, 2001) and author's calculations. 
By contrast, an NRC can be positive even though the sector on the whole performed below the national average (Type 3). Take the clothing sector as an example. The negative SC resulted in negative NRCs in virtually all provinces. Only in Jiangsu, Zhejiang, Fujian, Guangdong and Hainan did locational factors override this, resulting in positive NRCs in these provinces. In all other provinces location compounded the performance of the sector and dragged the growth rate further below average (Type 4). The machine-building sector provides a similar example, with only Zhejiang and Guangdong scoring positive NRCs. The point is that these provinces must have something working in their favour.

The results from Table 22.4 are summarised in Table 22.5. There are two main issues of interest. First is the number of sectors in which provinces record positive NRCs (Types 1,2,3), since this equates to above average growth and hence rising industry shares. Guangdong is the frontrunner with positive NRCs in 23 out of its 28 sectors. Zhejiang has 21 such sectors, followed by Fujian and Shanghai with 18 each and then Tianjin and Hebei with 15. Henan and Hubei (neighbouring central provinces) come in just behind with 14 sectors each. With at least half of their sectors growing above average, it is not surprising that these provinces (with the exception of Hubei) increased their shares of national manufacturing output over the period in question. ${ }^{10}$ Moreover, it shows that provincial growth rates are not necessarily contingent on the exceptional growth of one or two boom sectors, but instead derive from above average growth in the majority of sectors. This suggests that location rather than industry structure may be the main determinant of growth.

Building on this point, note that growth is above average in 16 out of the 28 sectors (positive values in the bottom row of Table 22.4). And yet Qinghai, Shaanxi and Inner Mongolia record positive NRCs in only six sectors. This implies that locational factors dragged 22 sectors in each province below average. The two coastal provinces of Liaoning and Guangxi perform even more poorly, recording positive NRCs in only five and three sections respectively. Producing output in sectors that grow above average (which all provinces do) is not enough to ensure above-average provincial growth. That is not to say that a 'lucky' sectoral structure doesn't help. Xinjiang, for example, only records positive NRCs in ten sectors, one of which is petroleum processing and coking, which experienced a growth rate close to double the national average. The fact that close to a third of Xinjiang's manufacturing output is produced in this sector explains Xinjiang's share of manufacturing output overall. This, however, is the exception rather than the rule. ${ }^{11}$ 
The second issue of interest is the number of sectors in which the locational component is positive, that is, location favours growth (Types 1, 3, 6). Guangdong and Zhejiang have 25 and 24 sectors in these three categories respectively, followed by Tianjin and Fujian with 18 each. Most other coastal provinces score highly on this front as well, other than Liaoning and Guangxi. Locating production in either of these provinces made a positive contribution to growth in just two sectors. This placed them behind all western provinces from Ningxia's 11 sectors to Sichuan's five.

For the central provinces, locational advantages tended to exist in relatively few sectors: three in Anhui and Hunan, four in Jiangxi, five in Heilongjiang, and so on. Henan (which increased its share of output) was a favourable location for growth in 15 sectors, placing it above numerous coastal provinces. Hubei also performed relatively well within the central region, with 11 sectors recording positive locational components. These figures are noteworthy from two perspectives. First, the overall performance of the region is well behind that of the East, suggesting that the gains from industrial development in the latter have not yet trickled down, or across as the case may be. However the delineation of East and Centre is somewhat blurry, particularly in light of the relatively strong performances of Henan and Hubei. Second, the average performance of the region in terms of sectors favoured by location is actually worse than the West's (7 sectors versus 8 ), with a significant number of central provinces ranking below their western counterparts. Given the present focus on western development, this is a significant point.

The emphasis here has been on the importance of locational factors in determining rates of manufacturing growth. This is not to say that industrial structure is irrelevant to provincial performance, as that is clearly not the case: those provinces blessed with a 'lucky' industrial structure (that is, relatively more production in sectors that are performing relatively well) will obviously perform better than those that are not. However, structure is simply not enough. In more than 70 per cent of the 1,108 NRC calculations in Table 22.4, the absolute value of the locational component is greater than the absolute value of the structural component. This implies that discrepancies in industrial performances across provinces stem more from discrepancies in provincial 'environments' than from discrepancies in their industrial structures. In other words, location matters. 
$\sqrt[5]{8}$

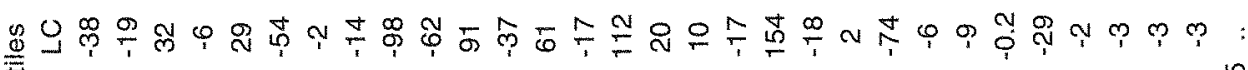

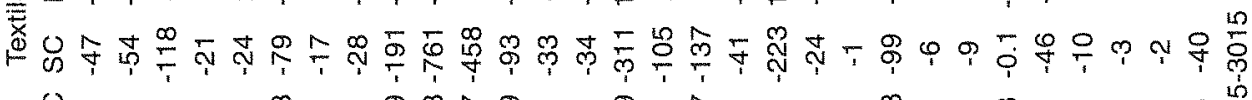

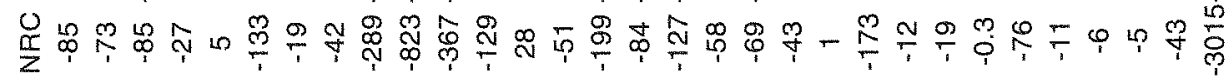

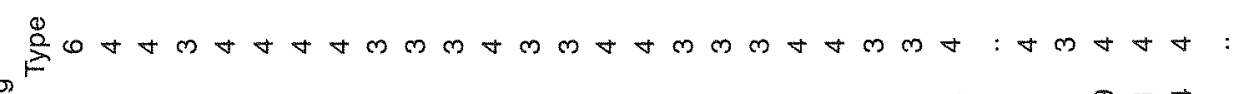

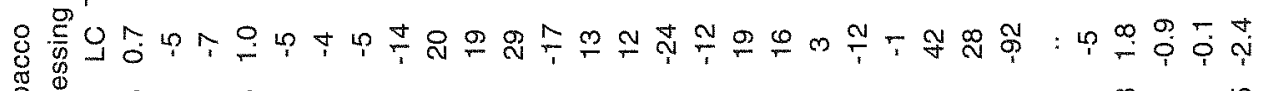

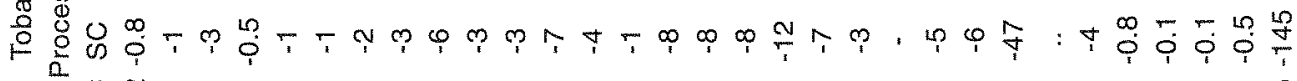

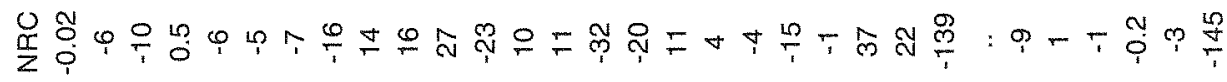
(n) ब.

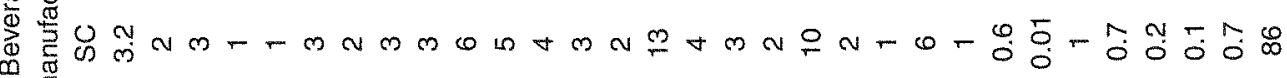

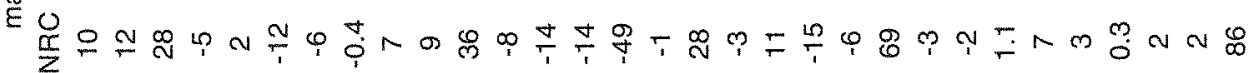
0
0 莺

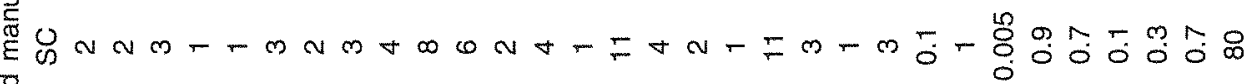

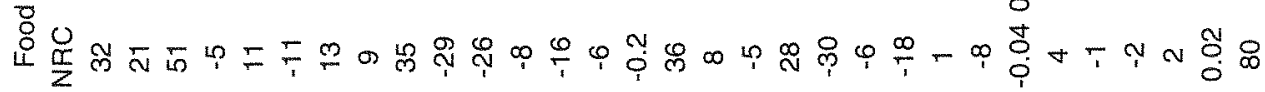

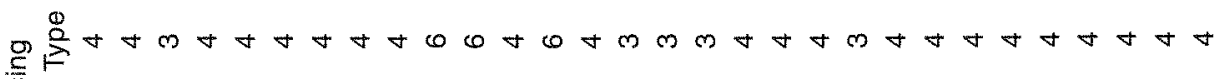
कू 势

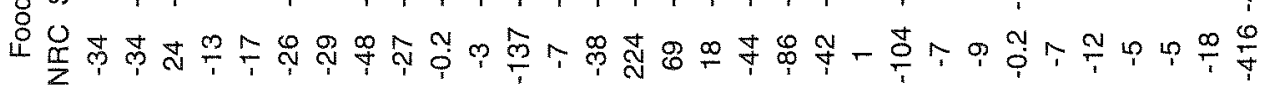


do 产 旁范 茎

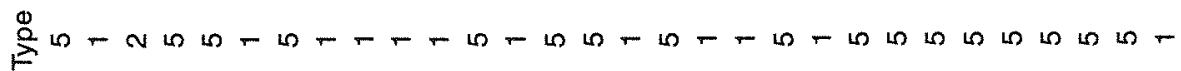

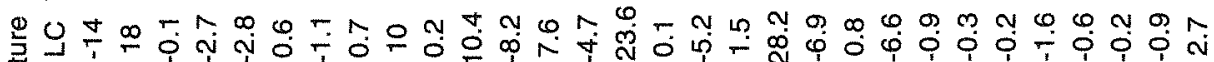

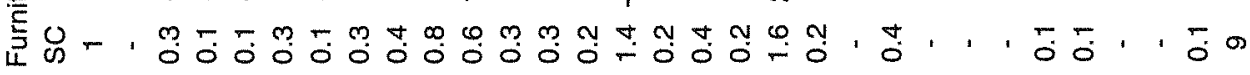
艺

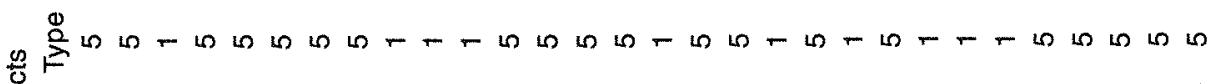

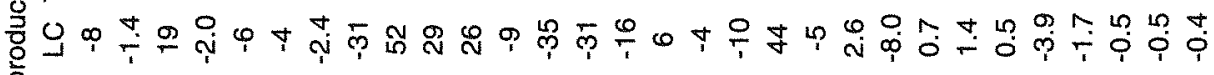
g $U$ 茂

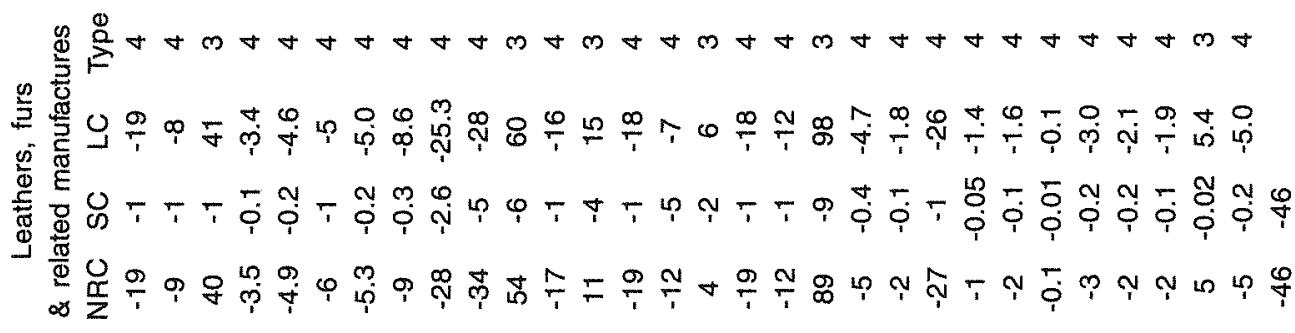

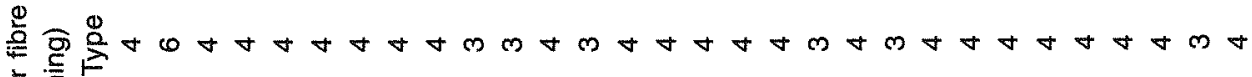

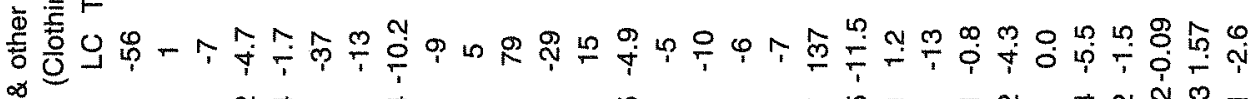

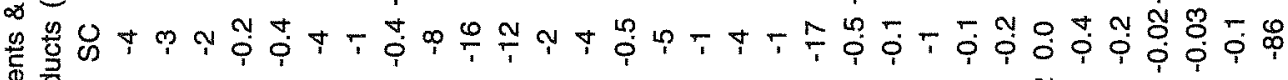

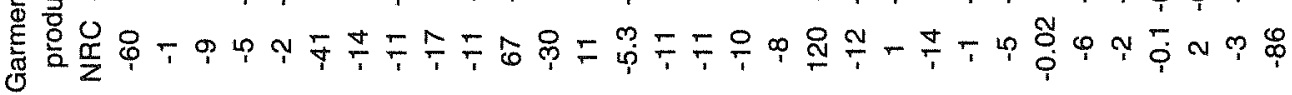

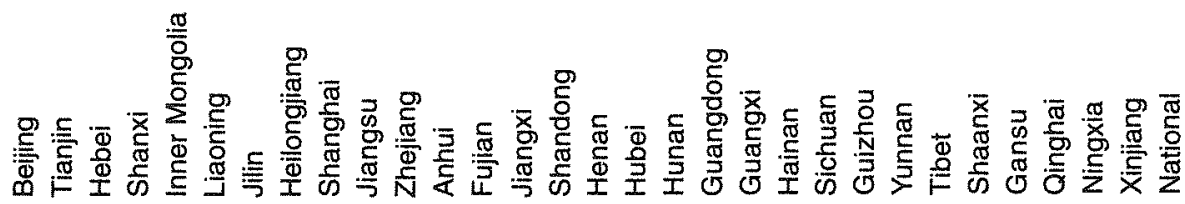




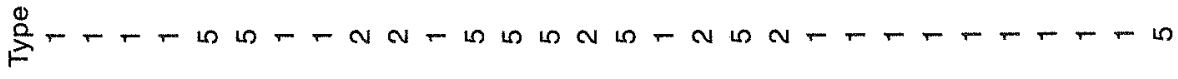

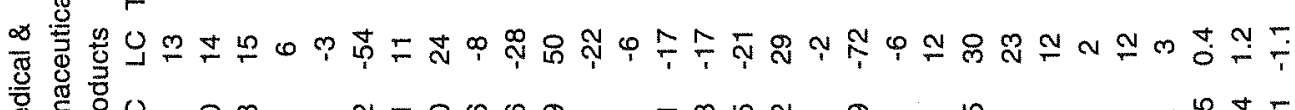

음

夰 $\bar{N}$

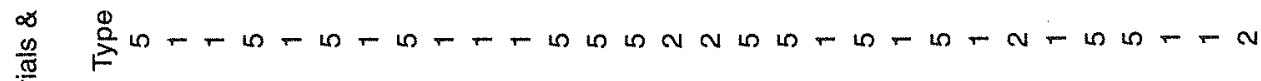

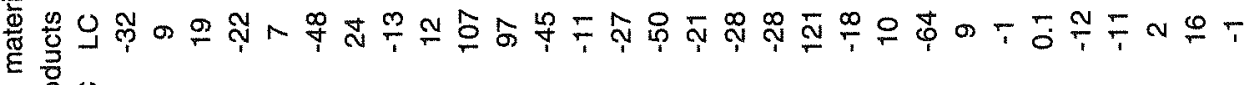
类造品

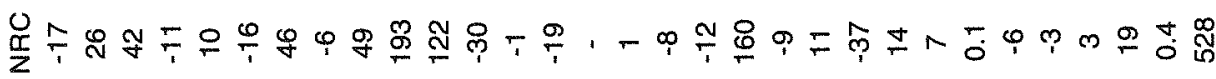

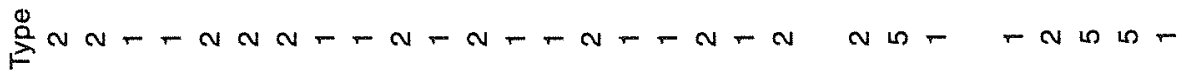

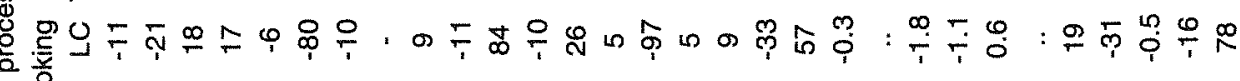

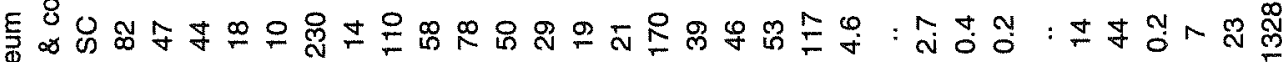

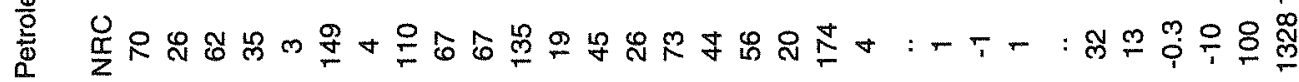

可 跑

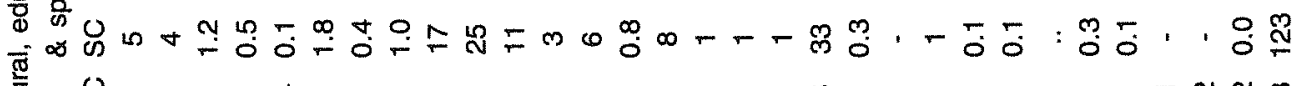

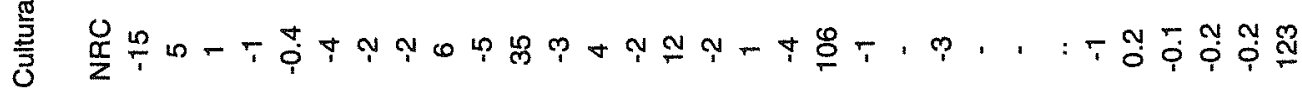

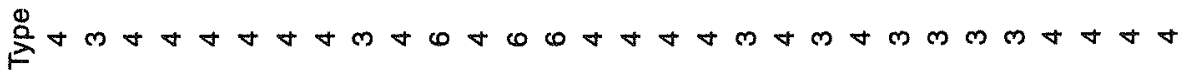

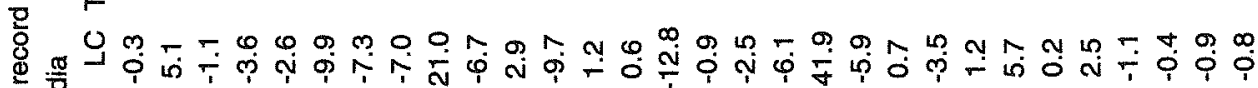

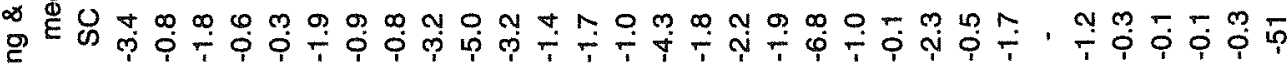
毫

芷

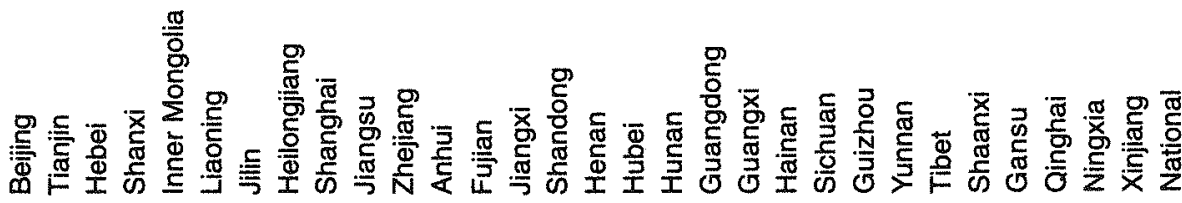




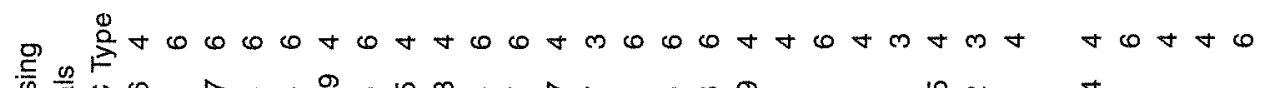

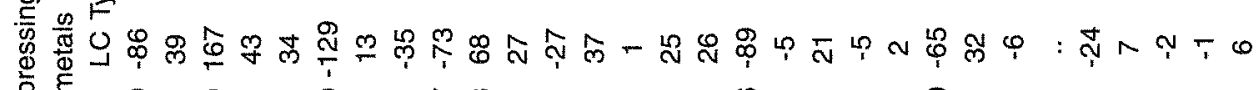

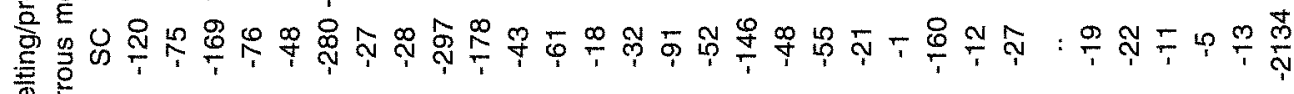
岕 西 厸

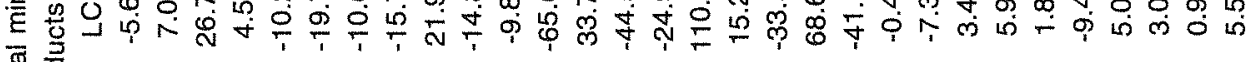
焉吾 है 号

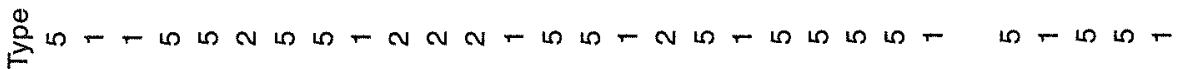

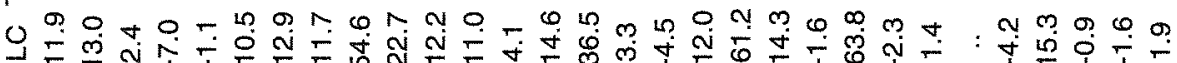
T T $1, T$ T

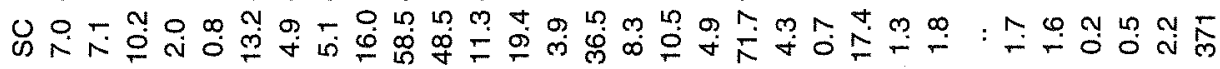

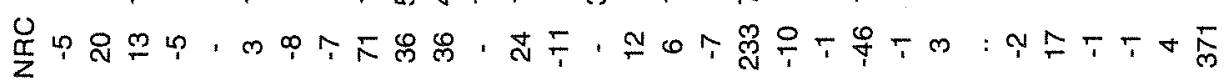

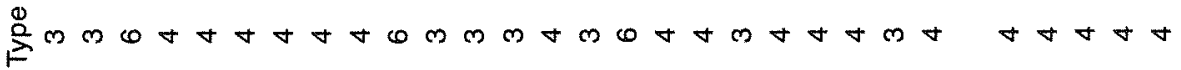

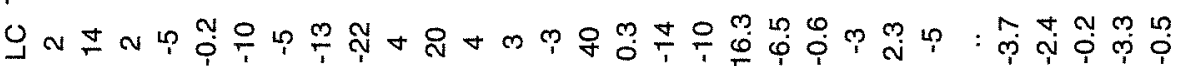

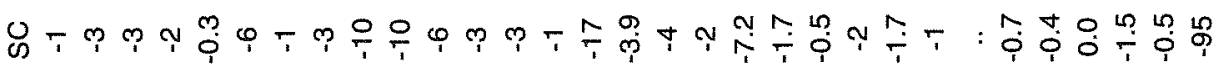

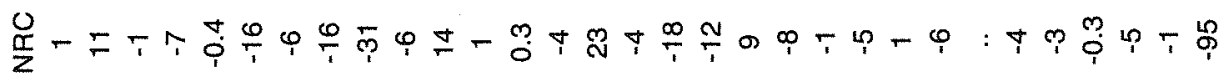

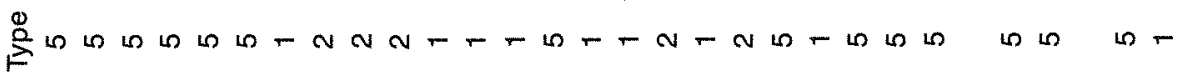
递

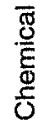

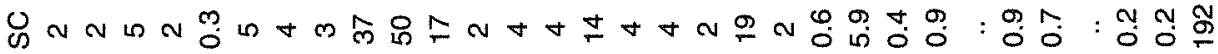

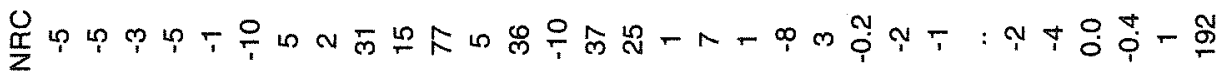

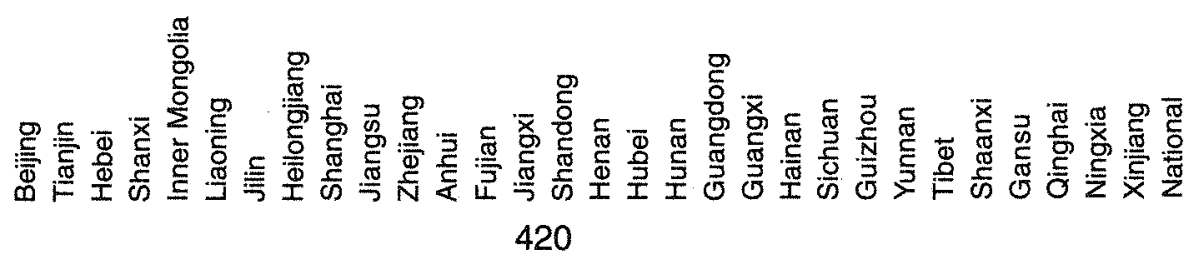




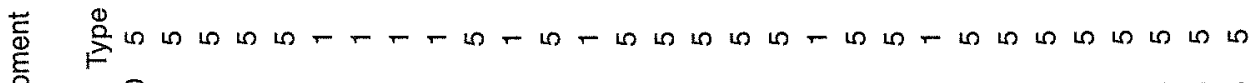
产

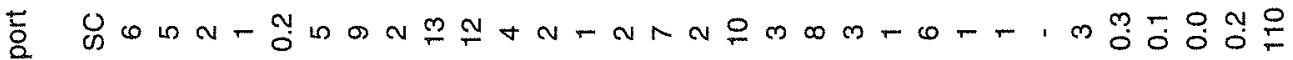

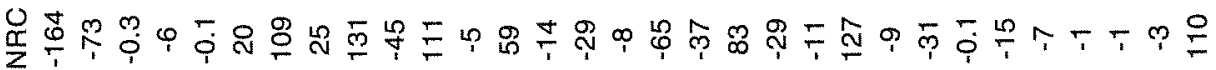

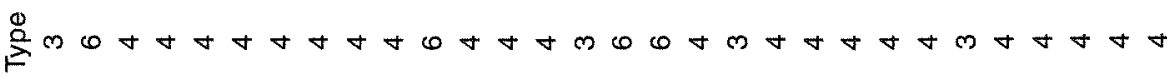
$\%$

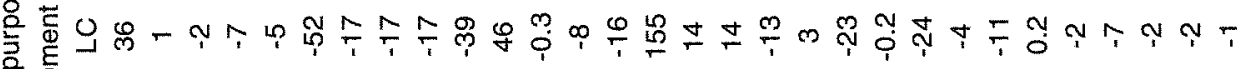

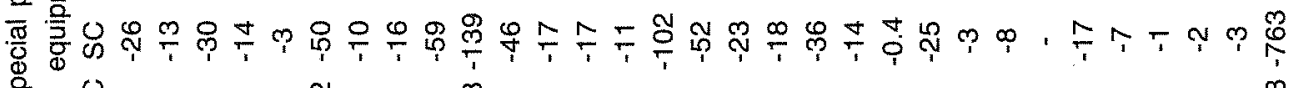

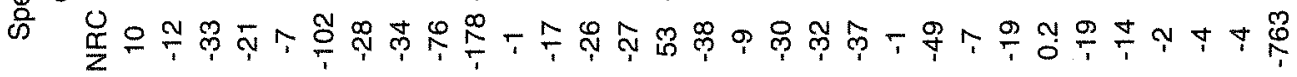
焉

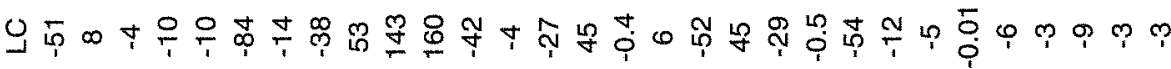

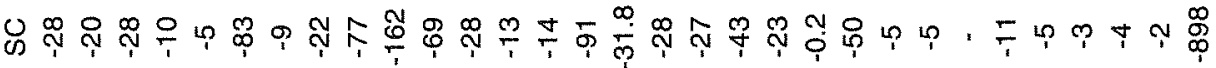

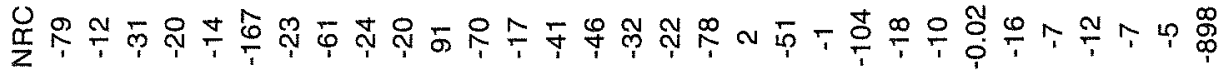

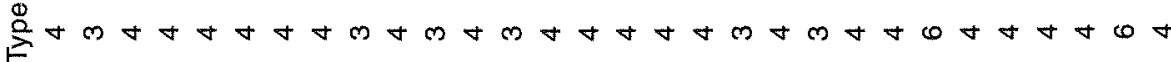

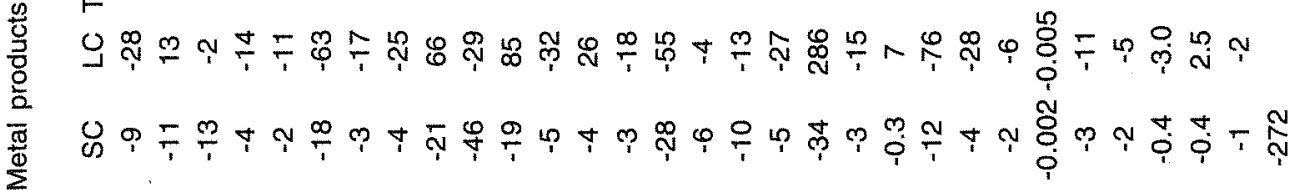
蒙

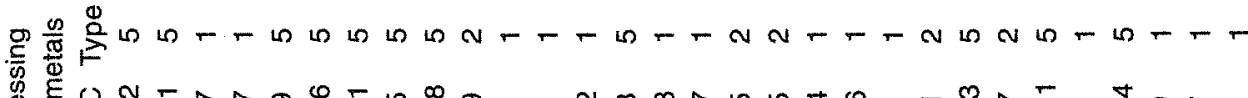

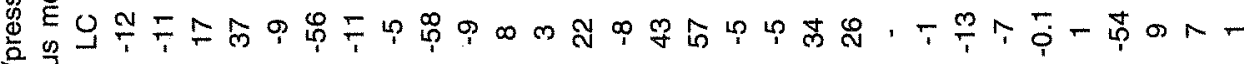
焉递品

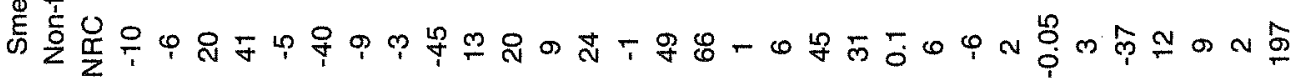

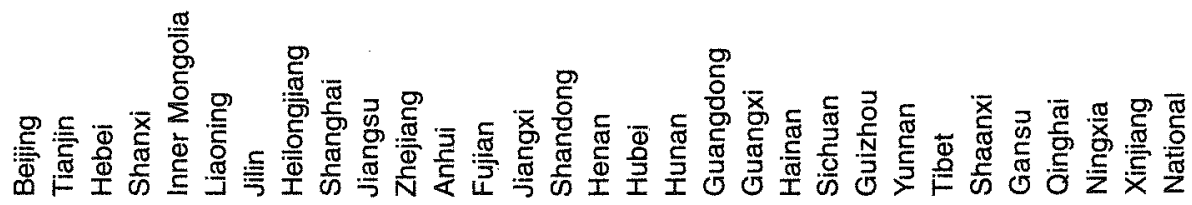




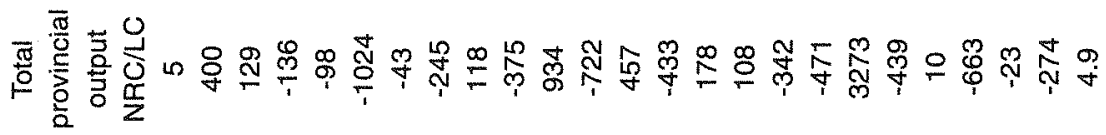

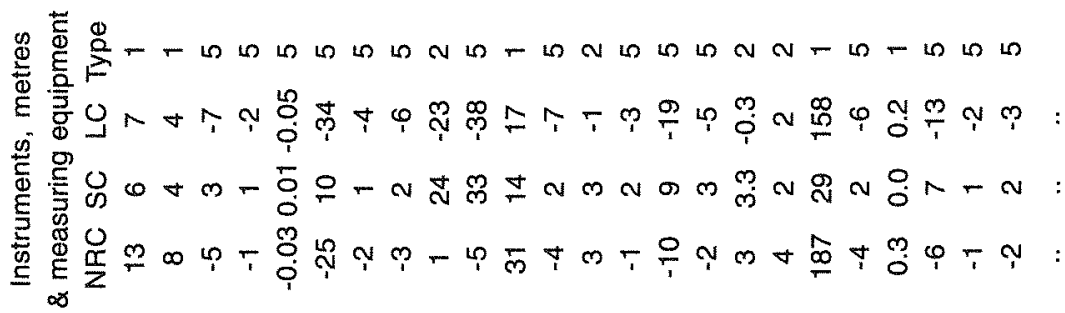

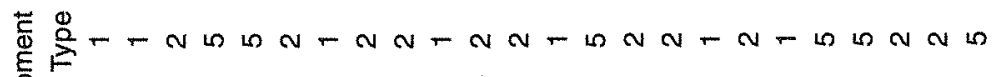

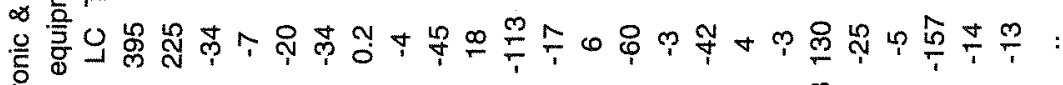

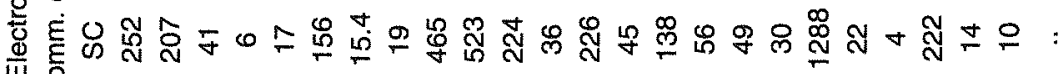

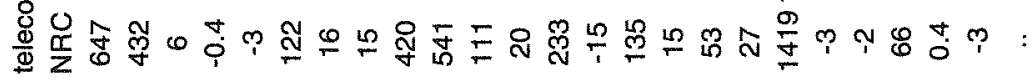

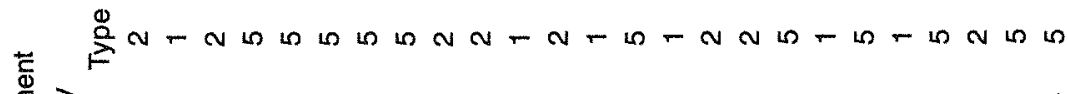

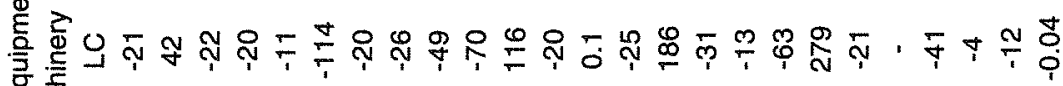

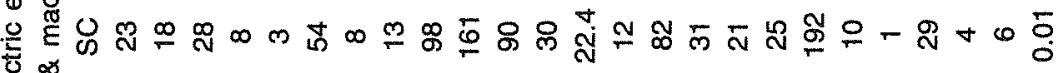

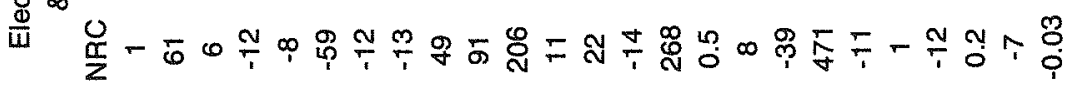

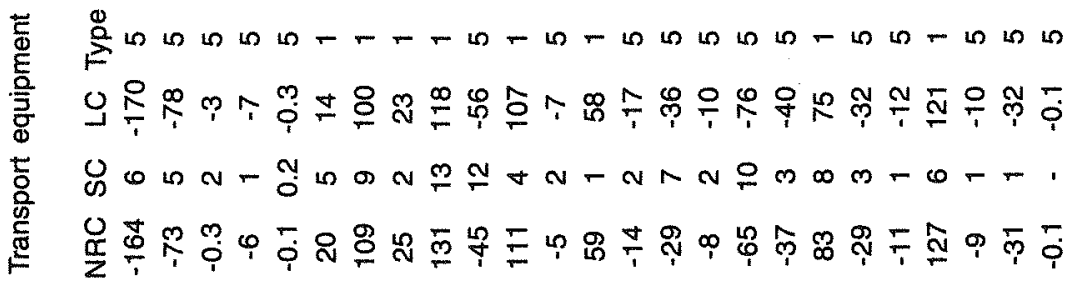

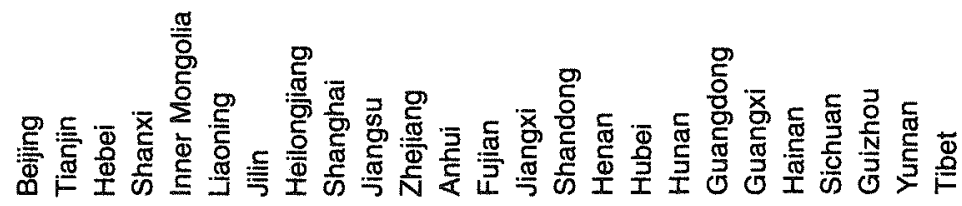
422 


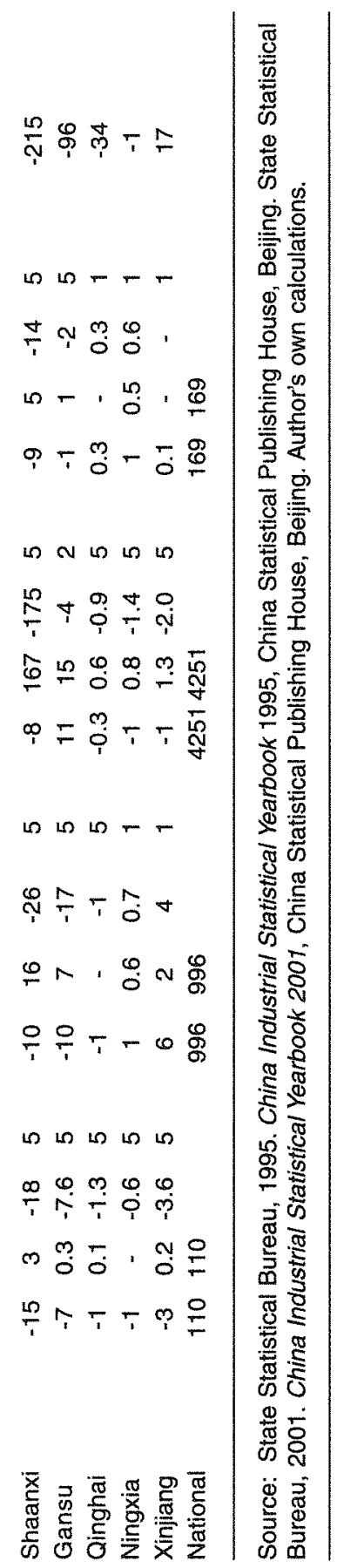




\section{POLICY ISSUES}

Having established that location matters, the crucial question for China's policymakers, which shift-share analysis does not provide any answers to, is whether or not they can influence the locational advantages of individual provinces in order to encourage industrial development in less developed areas. And if this is not the appropriate way to address regional inequality, what is? This section raises some key issues in this regard.

China's immense size and diversity suggest a natural tendency towards regional inequality. With populations ranging from 2.5 million in Tibet to 117 million in Sichuan, and areas ranging from roughly 6,000 square kilometres in Shanghai to 1.7 million square kilometres in Xinjiang, it should be rather obvious that patterns of development would not conform across provinces. This has certainly been the historical experience of China. As long ago as the Song dynasty (960-1279), the economic centre was shifting towards the coastal region. By the end of the Qing dynasty (1644-1911) foreigners began to invest in and establish foreign-run factories along the east coast. The concentration of industrial enterprises in coastal China increased through the second half of the nineteenth century, partly because of the opening of numerous treaty ports there. The Treaty of Nanjing saw the opening of Guangzhou, Fuzhou, Xiamen, Ningbo and Shanghai on the southeast coast to foreign economic activities. ${ }^{12}$ When market forces were re-introduced in the late 1970s, it seemed fairly natural that industrialisation would take up where it had left off prior to the era of command planning. Put simply, 'accidents of history' have favoured China's coastal provinces.

This historical background was clearly recognised by Deng Xiaoping in his Open Door Policy, which was a major initiative underlying the commencement of China's economic reforms. In 1979 four Special Economic Zones (SEZs) were established in Shenzhen, Zhuhai, Shantou (all in Guangdong) and Xiamen (in Fujian). SEZs were granted special administrative and economic powers and enjoyed tax breaks and other privileges. This initial kick-start to development began a cumulative process of industrial agglomeration, by making these provinces more attractive locations for both foreign-invested and domestic industrial production. Rising industrial profits generated higher incomes which, as a result of fiscal decentralisation, remained in provincial hands. Re-investment in infrastructure and other local-level services led to relative cost reductions, which further encouraged firms to locate in areas where success bred success. This process continues today. 
While extremely difficult to quantify, it is difficult to overlook the vital role that government policy has played. Guangdong provides the best example. While it certainly had the geographical advantage of proximity to Hong Kong, initial policy support through the central government's regional policies compounded this advantage, facilitating the rise of reform-minded provincial leaders who in turn came up with innovative local initiatives to obtain foreign capital and technologies and to

Table 22.5 Summary of types

\begin{tabular}{|c|c|c|c|c|c|c|c|c|c|c|}
\hline & \multicolumn{7}{|c|}{$\begin{array}{c}\text { Total number of sectors } \\
\text { in each category }\end{array}$} & \multirow{2}{*}{\multicolumn{2}{|c|}{$\begin{array}{cc}\text { Location Structure } \\
\text { favours } & \text { favours } \\
\text { growth } & \text { growth } \\
1+3+6 & 1+2+5\end{array}$}} & \multirow{2}{*}{$\begin{array}{c}\text { Positive } \\
\text { NRC } \\
1+2+3\end{array}$} \\
\hline & 1 & 2 & 3 & 4 & 5 & 6 & Sum & & & \\
\hline Beijing & 5 & 2 & 2 & 9 & 9 & 1 & 28 & 8 & 16 & 9 \\
\hline Tianiin & 10 & 2 & 3 & 4 & 4 & 5 & 28 & 18 & 16 & 15 \\
\hline Hebei & 9 & 4 & 2 & 6 & 3 & 4 & 28 & 15 & 16 & 15 \\
\hline Shanxi & 3 & - & 1 & 9 & 13 & 2 & 28 & 6 & 16 & 4 \\
\hline Inner Mongolia & 3 & 2 & 1 & 10 & 11 & 1 & 28 & 5 & 16 & 6 \\
\hline Liaoning & 2 & 3 & - & 12 & 11 & - & 28 & 2 & 16 & 5 \\
\hline Jilin & 6 & 1 & - & 11 & 9 & 1 & 28 & 7 & 16 & 7 \\
\hline Heilongjiang & 5 & 2 & - & 12 & 9 & - & 28 & 5 & 16 & 7 \\
\hline Shanghai & 9 & 6 & 3 & 7 & 1 & 2 & 28 & 14 & 16 & 18 \\
\hline Jiangsu & 6 & 6 & 2 & 6 & 4 & 4 & 28 & 12 & 16 & 14 \\
\hline Zhejiang & 13 & 2 & 6 & 1 & 1 & 5 & 28 & 24 & 16 & 21 \\
\hline Anhui & 2 & 4 & 1 & 11 & 10 & - & 28 & 3 & 16 & 7 \\
\hline Fujian & 8 & 3 & 7 & 2 & 5 & 3 & 28 & 18 & 16 & 18 \\
\hline Jiangxi & 1 & * & 1 & 9 & 15 & 2 & 28 & 4 & 16 & 2 \\
\hline Shandong & 5 & 4 & 3 & 6 & 7 & 3 & 28 & 11 & 16 & 12 \\
\hline Henan & 8 & 3 & 3 & 5 & 5 & 4 & 28 & 15 & 16 & 14 \\
\hline Hubei & 5 & 7 & 2 & 6 & 4 & 4 & 28 & 11 & 16 & 14 \\
\hline Hunan & 2 & 5 & 1 & 11 & 9 & - & 28 & 3 & 16 & 8 \\
\hline Guangdong & 14 & 1 & 8 & 1 & 1 & 3 & 28 & 25 & 16 & 23 \\
\hline Guangxi & 1 & 2 & - & 11 & 13 & 1 & 28 & 2 & 16 & 3 \\
\hline Hainan & 9 & 1 & 6 & 5 & 5 & 1 & 27 & 16 & 15 & 16 \\
\hline Sichuan & 3 & 3 & 1 & 10 & 10 & 1 & 28 & 5 & 16 & 7 \\
\hline Guizhou & 4 & 2 & 5 & 7 & 10 & - & 28 & 9 & 16 & 11 \\
\hline Yunnan & 4 & 3 & 2 & 9 & 9 & 1 & 28 & 7 & 16 & 9 \\
\hline Tibet & 4 & - & 3 & 6 & 5 & - & 18 & 7 & 9 & 7 \\
\hline Shaanxi & 5 & - & 1 & 11 & 11 & - & 28 & 6 & 16 & 6 \\
\hline Gansu & 4 & 2 & 1 & 9 & 10 & 2 & 28 & 7 & 16 & 7 \\
\hline Qinghai & 5 & * & 1 & 11 & 10 & 0 & 27 & 6 & 15 & 6 \\
\hline Ningxia & 7 & 1 & 2 & 8 & 8 & 2 & 28 & 11 & 16 & 10 \\
\hline Xinjiang & 8 & 2 & - & 10 & 6 & 2 & 28 & 10 & 16 & 10 \\
\hline National average & 6 & 2 & 2 & 8 & 8 & 2 & 28 & 10 & & 10 \\
\hline
\end{tabular}


promote non-state sector developments (Chung 1997). As a recent article points out, 'Twenty years ago Shenzhen was a small, non-descript area of three square kilometres with a population of 30,000. Ten years later it was a cluster of labourintensive processing workshops. Today it is the most developed and compact hitech area on China's mainland' (China Today, 2003:13). Recently Shenzhen has obtained further rights to experiment with WTO-related reforms ahead of the rest of the country, which should enable the city to continue its role as China's 'pacesetter'. In light of these continuing advantages, no wonder Guangdong remains China's most desirable location for industrial production, with agglomeration there still on the rise.

Guangdong is not the only province to have benefited from preferential treatment by the central government, although the timing of central government support for the reform process varies. Surely not coincidentally, so does the timing of rapid economic growth. The Shanghai people have identified 'policy gifts' from the centre as the crux of the economic reform process. 'Policy is wealth', according to one of their vice-mayors. ${ }^{13}$ As Jacobs (1997) argues convincingly, it is not difficult to see how they have reached this conclusion. At the end of the 1980s Shanghai was still tightly controlled by the central government, in large part due to the centre's heavy reliance on the municipality for revenues. In 1990 the Pudong area-subsequently China's fifth SEZ-was opened, offering incentives such as tax holidays, a freetrade zone, and extended land leases. Following that, Shanghai's enterprise tax rates were lowered and policies permitting the establishment of the stockmarket, futures exchanges and liberal foreign investment policies have attracted funds from both overseas and domestic investors. In other words, Shanghai has benefited from policy rather than funds from centre.

Prior to 1990 Shanghai's share in the gross value of China's industrial output declined continually while growth rates of real GDP and per capita GDP were consistently below average (Table 22.2). However since the early 1990s this situation has reversed, with Shanghai recording annual real GDP growth above the national average between 1993 and 2001. In 2002 Pudong recorded its highest investment in fixed assets and highest materialisation rate of foreign investment to date, with GDP increasing by 16.7 per cent over the previous year. This made 2002 the twelfth consecutive year of two-digit growth for Pudong (China Today April 2003:26-27). The shift-share analysis provides further evidence of this dramatic turnaround for Shanghai. In contrast with a similar analysis conducted between the years 1989 
and 1994, in which only four sectors recorded locational components working in their favour, Shanghai recorded 14 sectors with positive locational components between 1994 and 2000. Similarly, 18 sectors recorded positive NRCs during the period 1994-2000, compared with only seven sectors in the previous period. A similar reversal has clearly not been experienced by Liaoning or Guangxi, coastal provinces which appear to be relatively neglected on the preferential policy front. This is hardly proof that policy is the definitive cause of industrial success, but it certainly suggests that it has a role to play.

Unfortunately the claim that policy has assisted industrial development via creating locational advantages in certain coastal provinces does not lead to an equally valid claim that this could be repeated with success in China's interior. The most significant difference is that Deng's decision to favour the coastal region compounded the natural tendency-stemming from historical, geographical, political, cultural and other factors-towards regional inequality. In contrast, the 'Go West Campaign' appears to be aiming to counteract this natural tendency, making the current task inherently different and also more difficult. But that does not necessarily make it impossible.

The natural process of industrial agglomeration in a market economy is not boundless. Instead, rising costs in industrialising regions, combined with falling transport, transactions and other costs of doing business across regions, should eventually encourage firms to relocate to less developed regions. The shift-share analysis suggests that this process of trickle down remains fairly confined to the coastal provinces and a few neighbouring central provinces. ${ }^{14}$ An equalising regional policy is thus a question of how best to speed up this process.

It is tempting to suggest a set of central government policies which improve the 'locational advantages' of less developed regions. The key idea is that the 'coreperiphery' pattern could be reversed if policy measures were able to tilt the pattern of industrial production in favour of peripheral areas. Preferential policy measures such as investment and credit incentives could reduce the relative costs of producing in Peripheral areas. Subsidies to specific industries in certain regions or expenditure on local infrastructure could, theoretically, serve a similar purpose. Alternatively, direct fiscal transfers from richer to poorer areas should increase expenditure in the latter, thereby strengthening demand linkages there. However, the vast differentials in present industrial capabilities across provinces would require significant expenditure by the central government in order to create locational advantages-or agglomeration 
forces - which could outweigh those already firmly established in the coastal region. Weak central government finances and the sheer size of the problem (that is, western and most of central China), combined with problems such as 'picking winners'either in terms of industries or locations-suggest that in reality such measures are highly unlikely to prove effective. China's entry into the WTO, and the consequent increase in foreign involvement in virtually all industrial sectors alongside various requirements regarding non-discrimination (between state-owned and private firms, and also among provinces), further constrain the central government's options in this category.

A superior set of policy measures focuses on reducing broadly defined 'transport costs'. A key point to observe is that initial reductions in transport costs will actually worsen regional inequality (as we observe in the case of China). In other words, this set of measures necessarily focuses on the medium to long term. The underdeveloped transport system is only one factor contributing to the overall cost of doing business at a distance within China's domestic economy. Expenditure on the national transport system clearly reduces the costs of relocating to distant, peripheral areas. The Qinghai-Tibet Railway project, scheduled for completion by the end of 2006, is one example of this kind. Beyond efforts to reduce physical costs, policy could aim to reduce the informational, sales and support costs of doing inter-regional business by improving the provision and transmission of information. This could be accomplished by expanding telecommunications networks, providing access to computers and the Internet, organising inter-regional trading organisations and so on. Similarly, continued efforts to eliminate administrative and other ad hoc barriers to inter-provincial trade-or to integrate the domestic market-should encourage the dispersal of industry to hitherto underdeveloped provinces. ${ }^{15}$ The central government's call for 'mutually beneficial co-operation' between coastal and interior provinces in the Ninth Five-Year Plan is just one example of a potentially effective policy in this regard. While some of these measures would be costly, if implemented without regional bias they would at least overcome potential problems associated with 'picking winners'. Moreover, rather than attempting to counteract market forces, policy measures in this category simply seek to speed up the process of relocation which is an inherent part of industrial development in an increasingly marketised system.

Aside from central government policies, provincial governments can seek more actively to create economic environments that are conducive to industrial 
development. As one example of this, a recent Beijing Review (20 February 2003:3436) article discusses how in the last two years Qinghai Provincial government has revised its 300 economic laws and regulations in accordance with international practice and formulated a set of preferential policies to protect the interests of foreign investors. It has chosen projects in industries with 'strong potential', including nonferrous metals, salt chemicals and medicine in order to attract foreign investors. (It is perhaps a coincidence that the positive locational component accounted for 66 per cent of the positive NRC on Qinghai's smelting/pressing nonferrous metals and chemical materials, and that its NRC and locational component for medical and pharmaceutical products were also positive). This is more likely to succeed at a provincial level than a national one (although success is far from guaranteed). According to Wu Dawei, Director of the Department of Foreign Trade and Economic Co-operation of Qinghai, the policies have succeeded in bringing substantial increases in foreign investment to the province: foreign-funded enterprises invested US $\$ 270$ million in 2001, a 25 per cent increase over the previous year, and in the first half of 2002 they had already invested US $\$ 347$ million, a 130 per cent increase over the same period in 2001. While this evidence is anecdotal, it does suggest that provinciallevel policies may be important. They would perhaps be even more so in combination with an increased focus on the 'transport cost' category of policies at the central government level.

\section{CONCLUSIONS}

China's current trends in the growth of provincial and regional per capita income, underpinned by a process of industrial agglomeration, suggest that the central government has quite a challenge on its hands given its current objective of alleviating the regional inequalities that it has hitherto helped to promote.

The inverted U-shaped relationship between industrial agglomeration and 'transport costs', which in their very broadest sense provide a proxy for economic development (Krugman 1995) clarifies the notion that these trends are, to a large extent, a natural consequence of economic development in a market economy. On the upside of the $U$, firms and workers choose to locate near other firms in order to benefit from cost and demand linkages and other externalities associated with larger markets, which in turn draws in more and more firms and workers. During this phase, regional inequalities rise. There is ample empirical evidence to suggest that China remains on this side of the process. On the downside of the $U$, firms relocate in order to 
benefit from lower wages and other costs associated with industrial production in hitherto less developed areas. The theoretical endpoint of this process is an even distribution of industry and incomes across space. While this is unlikely to be the case in reality, an equalising regional policy becomes a question of how best to speed up the process of relocation. Although this is a question without obvious or simple answers, the empirical analysis and discussion above provide a few key points.

The shift-share analysis enabled us to identify locations where industrial performance appears to be above average for no reason other than that production was located in that area, and not elsewhere: location matters. The identification of certain coastal provinces as those locations confirmed that industrial agglomeration is an important component of the continuing rise in regional income inequality. But the methodology also enabled us to identify that some coastal provinces, particularly Liaoning and Guangxi, and virtually all the central provinces, were among the worst performers during the period in question. Given the current focus on western development, it is important to recognise the potential for non-western provinces to become areas of neglect in terms of regional policy formulation. Moreover, it is necessary to continually update the analysis in order to pinpoint how the 'winners' and 'losers' are changing over time.

The recognition that regional development is a dynamic process in which the beneficiaries certainly do change over time points to the difficulties a central government would face in trying to pick winners by directing (limited) fiscal resources either to specific industries or provinces. In an increasingly marketised and internationally integrated economy, it is better to leave the decisions of where to invest to the firms themselves, while provincial and lower level governments focus on making their own localities competitive as locations for investment. Central fiscal resources would be much better spent on efforts to reduce the physical and other costs of relocating to distant areas. Policies promoting the integration of the domestic economy fall into this category and would increase the likelihood that the benefits of industrialisation and WTO entry will benefit provinces beyond those in the current industrial Core. While more effort is needed to establish exactly what policies stand the greatest chance of alleviating China's regional inequalities, taking into account the issues addressed here will at least raise the likelihood of success. 


\section{NOTES}

1 This does not imply that the policy goal was successful, as this levelling came at significant cost.

2 Of course industrial development is not the only aspect of development that matters, but it certainly features significantly in China's policy agenda.

3 See Golley (2000) for a much more comprehensive discussion.

4 Hirschman (1958) and Myrdal (1957) introduced the terms 'trickle down' and 'spread' respectively to describe the eventual levelling out of development across regions within a country.

5 See Golley (2000) for a more detailed justification of using 'transport costs' as proxy for China's transition process.

6 See Golley $(2000,2002)$.

7 This method is adapted from Liu, Yao and Zhang (1999).

8 Golley (2002) conducts a similar analysis for the period 1989-94. This section will make reference to some of those results.

9 Further evidence of this claim is provided in Golley $(2000,2002)$.

10. Whether or not total output shares rise clearly depends on how much of their output is derived from sectors growing above average. Space limitations prevent a closer analysis of this point.

1 Again, space limitations prevent a more detailed analysis of sectoral shares in each province, which would validate this point.

12 Golley (2000) discuss these issues in much more detail. See also Yang (1997).

13 Xie Kequiang, quoted in Jacobs (1997:169).

${ }^{14}$ See Brun, Combes and Renard (2002) for further evidence of this.

15 Young (2000) and Poncet (2002) discuss China's lack of domestic market integration.

\section{REFERENCES}

Bao Shuming, Gene Hsin Chang, Sachs, J. and Wing Thye Woo, 2002. 'Geographic factors and China's regional development under market reforms, 1978-1998' China Economic Review, 13(1):89-111.

Brun, J.F., Combes, J.L. and Renard, M.F., 2002. 'Are there spillover effects between coastal and noncoastal regions in China?', China Economic Review, 13(2-3):16169.

Chung, J., 1997. 'Shandong: the political economy of development and inequality', in D.S.G. Goodman (ed.), China's Provincial Reform: class, community and political culture, Routledge, London:127-57. 
Démurger, S., 2001. 'Infrastructure development and economic growth', Journal of Comparative Economics, 29(1):95-117.

Deng Xiaoping, 1984. On SEZs and Opening More Cities to the Outside World, Excerpt from a talk with several senior comrades of the Central Committee of the Chinese Communist Party (CCCCP), Beijing, 24 February. Reprinted in Deng Xiaoping (1987), Fundamental Issues in Present Day China, Foreign Languages Press, Beijing:43-45.

- 1986. Take a Clear Cut Stand Against Bourgeois Liberalisation, Remarks on recent student disturbances made to some leading members of the CCCCP, Beijing, 30 December. Reprinted in Deng Xiaoping (1987), Fundamental Issues in Present Day China, Foreign Languages Press, Beijing:161-66.

_-, 1987. Fundamental Issues in Present Day China, Foreign Languages Press, Beijing.

Fujita, M. and Hu, D., 2001. 'Regional disparity in China 1985-1994: the effects of globalisation and economic liberalisation', Annals of Regional Science, 35(1):337.

Golley, J., 2000. The Dynamics of Regional Development during China's Economic Transition, Dphil Dissertation, Oxford University, Oxford.

- 2002. 'Regional patterns of industrial development during China's economic transition', Economics of Transition, 10(3):761-801.

Goodman, D. (ed.), 1997. China's Provincial Reform: class, community and political culture, Routledge, London.

Hirschman, A., 1958. The Strategy of Economic Development, Yale University Press, New Haven.

Jacobs, B.J., 1997. 'Shanghai: an alternative centre?', in D.S.G. Goodman (ed.), China's Provincial Reform: class, community and political culture, Routledge, London:163-93.

Krugman, P., 1991. Geography and Trade, Leuven University Press and MIT Press, Cambridge, Massachusetts.

- 1995. Development, Geography and Economic Theory, MIT Press, Cambridge, Massachusetts.

Lardy, N., 1978. Economic Growth and Distribution in China, Cambridge University Press, Cambridge.

Liu, A., Yao, S. and Zhang, Z., 1999. 'Economic growth and structural changes in employment and investments in China, 1985-94', Economics of Planning, 32(3):171-90. 
Lyons, T., 1991. "Inter-provincial disparities in China: output and consumption, 19521987', Economic Development and Cultural Change 39(3):471-506.

Myrdal, G., 1957. Economic Theory and Underdeveloped Regions, Gerald Duckworth, Essex.

Mody, A. and Fang-Yi Wang, 1997. 'Explaining industrial growth in coastal China: economic reforms... and what else?", World Bank Economic Review, 11(2):293325.

Poncet, S., 2002. 'Measuring Chinese domestic and international integration', China Economic Review, 14(1):1-22.

State Statistical Bureau, 1997. The Gross Domestic Product of China, 1952-95, Dongbei University of Finance and Economics Press, Dalian.

State Statistical Bureau, various years. Statistical Yearbook of China, China Statistical Publishing House, Beijing.

State Statistical Bureau, various years. China Industrial Economic Statistical Yearbook [Zhongguo Gongye Jinji Tongji Nianjian], China Statistical Publishing House, Beijing.

Yang, D., 1997. Beyond Beijing: liberalization and the regions in China, Routledge, New York.

Yao, S., 1997. 'Industrialisation and spatial income inequality in rural China, 198692', Economics of Transition, 5(1):97-112.

Yao, S. and Zhang, Z., 2001. 'On regional inequality and diverging clubs: a case study of contemporary China', Journal of Comparative Economics, 29(3):46684.

Young, A., 2000. 'The razor's edge: distortions and incremental reform in the People's Republic of China', The Quarterly Journal of Economics, 115(4):1091-135.

Zhao, Z., Documents of the Thirteenth National Congress of the Communist Party of China, Foreign Languages Press, Beijing.

Zeng Peiyan, 2000. Implementing the Strategy for Western Region Development, Interview conducted by Li Rongxia, Beijing Review, 29 May:22-24.

Ziyang, Z., 1987. Documents of the Thirteenth National Congress of the Communist Party of China, Foreign Languages Press, Beijing.

Zhu, R., 2000. Opening Address at the Third Session of the Ninth National People's Congress, Beijing, 5 March. 